\title{
Fish Diversity in a Kumaun Himalayan River, Kosi, at Almora Uttarakhand. India.
}

\author{
Babita Selakoti \\ Department of Zoology, R. H. Govt. P. G. College Kashipur, Udham Singh \\ Nagar. Uttarakhand, India.
}

\begin{abstract}
-
The present study deals with the ichthyofaunal diversity in the river Kosi at Almora district Uttarakhand. During the whole study period (Jan. 2013 to Dec. 2013) 12 species of fish fauna were observed. All the recorded fish species belonged to the families Cyprinidae and Botinae. Cyprinidae was the dominant family having 9 fish species out of the 12 species. The family Botinae comprised of 3 fish species.
\end{abstract}

Key words- Fish diversity, Kumaun Himayala, Kosi river, Kosi village.

\section{Introduction-}

Fishes are the important part of the world-class nonvegetarian food. These are the rich and excellent source of dietary protein. A number of countries are depending on the fish production for their economy. India possesses the ninth position among the world's largest freshwater biodiversity countries [13]. In the ecological studies the factors those affect the species richness are the main points of focus. The growth and survival of fish fauna depends on the food availability in the water resource. Zooplankton and phytoplankton are the prime food stuffs for the fishes. Not only the food but the physico-chemical conditions of the water, also play a major role in survival of fish faunal diversity. Many ecologists mentioned that the richness and occurrence of fish faunal diversity of any aquatic ecosystem conflicts with the environmental factors surrounding it [2]. Physico-chemical parameters such as $\mathrm{P}^{\mathrm{H}}$, conductivity, hardness, alkalinity, temperature of water etc. are some of the factors which determine the quality of water, which in turn, influence the productivity of fish fauna. The food of fishes i.e. zooplankton and phytoplankton also affects by the physico-chemical characteristics of the water.

The variety of ichthyofauna is declining at an alarming rate [3]. Environmental factors such as deterioration of water, overfishing, construction on riverside, use of bleaching powder, growth of ichthyotoxic plants etc. have caused the alteration of ecology of the rivers of mountain region. The disturbance in ecology of river ultimately results in depletion of fish species. Therefore the considerable attention is needed on the eco-biological aspects of the mountain rivers in order to maintain the natural potential of the river water for the survival and growth of fish species. Many studies have been done on the fish species diversity [4], [5], [16], [6], [17]. The freshwater ecosystem of Himalaya is highly diverse, that is important for the variation of aquatic population. Various studies have been done on the ecology and fish faunal diversity of the hill stream fishes [9], [11], [12]. The present investigation is a study on the present fish species in the Kosi river at Almora district. The river Kosi flows along the highway and is subjected to face the dust pollution, time to time, caused by the cutting of mountains for the road construction etc. Therefore the study of fish species diversity in the river Kosi is necessary to maintain the ecological balance of the river.

\section{Materials And Method}

The present study was conducted from January 2013 to December 2013 on Kosi river at Almora district. The village Kosi was selected as the sampling site. The site Kosi has an altitude of 1650 asml. The fish species were collected monthly from the site with 
the help of fishermen. All the collected samples were preserved into $10 \%$ formalin solution. The specimen of the fishes was identified with the help of different books and keys [7], [8].

\section{Results}

During the present research work on Kosi River a total 12 species of fish fauna were observed. The fish species found in the river, during the entire study period (Jan., 2013 to Dec., 2013) are listed under the table 1.

\begin{tabular}{|c|c|c|c|c|c|c|}
\hline $\begin{array}{l}\dot{0} \\
\dot{\bar{z}}\end{array}$ & 坣 & 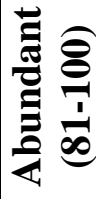 & 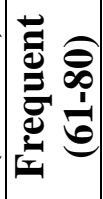 & 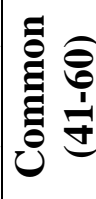 & 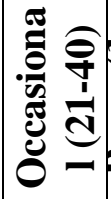 & 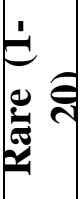 \\
\hline \multicolumn{7}{|c|}{ CYPRINIDAE } \\
\hline 1 & T. putitora & $\sqrt{ }$ & & & & \\
\hline 2 & T. tor & & & $\sqrt{ }$ & & \\
\hline 3 & $\begin{array}{c}S . \\
\text { richardsonii }\end{array}$ & $\sqrt{ }$ & & & & \\
\hline 4 & $\begin{array}{c}\text { S. } \\
\text { plagiostomu } \\
S\end{array}$ & $\sqrt{ }$ & & & & \\
\hline 5 & B. bendelisis & & $\sqrt{ }$ & & & \\
\hline 6 & B. varga & & & $\sqrt{ }$ & & \\
\hline 7 & G. gotyla & $\sqrt{ }$ & & & & \\
\hline 8 & $\begin{array}{c}\text { L. } \\
\text { dyocheilus }\end{array}$ & & & $\sqrt{ }$ & & \\
\hline 9 & L. dero & & & $\sqrt{ }$ & & \\
\hline \multicolumn{7}{|c|}{ BOTINAE } \\
\hline 1 & N. beavani & & & & $\sqrt{ }$ & \\
\hline 2 & N. rupicola & & & $\sqrt{ }$ & & \\
\hline 3 & N. montanus & & & & $\sqrt{ }$ & \\
\hline
\end{tabular}

Table 1: Observation of fish species present at sampling site kosi of Kosi River during entire study period (Jan., 2013 to Dec., 2013).

The identified fish species collected from the river were belonging to the families Cyprinidae and Botinae. Cyprinidae was the dominant family over

\begin{tabular}{|c|c|l|}
\hline $\begin{array}{c}\text { S.N } \\
\mathbf{0}\end{array}$ & $\begin{array}{c}\text { Familie } \\
\text { S }\end{array}$ & \multicolumn{1}{|c|}{ GENERA / SPECIES } \\
\hline \multicolumn{2}{|c|}{ CYPRINIDAE } \\
\hline $\mathbf{1}$ & & Tor putitora \\
\hline $\mathbf{2}$ & & Tor tor \\
\hline $\mathbf{3}$ & & Schizothorax richardsonii \\
\hline $\mathbf{4}$ & & Schizothorax plagiostomus \\
\hline $\mathbf{5}$ & & Barilius bendelisis \\
\hline $\mathbf{6}$ & & Barilius varga \\
\hline $\mathbf{7}$ & & Garra gotyla \\
\hline $\mathbf{8}$ & & Labio dyocheilus \\
\hline $\mathbf{9}$ & & Labio dero \\
\hline & BOTINAE \\
\hline $\mathbf{1 0}$ & & Noemacheilus beavani \\
\hline $\mathbf{1 1}$ & & Noemacheilus rupicola \\
\hline $\mathbf{1 2}$ & & Noemacheilus montanus \\
\hline
\end{tabular}

Botinae, consisting nine species and the family Botinae consists three species. On the basis of percentage of frequency of occurrence the fish species were categorized in to five categories Abundant (81-100\%), frequent (61-80\%), Common (41-60\%), Occasional (21-40\%) and Rare (1-20\%) Table (2).

Table 2: Observation of percent frequency of occurrence of fish fauna at sampling site kosi of Kosi River during entire study period (Jan., 2013 to Dec., 2013).

After the observation of fish species collected from the sampling station throughout the study period three fish species ( $S$. richardsonni, $S$. plagiostomus and $G$. gotyla) were noted to be present throughout the year. $100 \%$ of frequency of occurrence was calculated for the above mentioned fish species and were noted to fall under the category of abundant. Tor putitora was noted 91.67 $\%$ frequent in occurrence during the study period and categorized under the abundant category. Only one species Berilius bendelisis (66.67\% frequency of occurrence) was noted to fall under the frequent category. A total five fish species Tor tor (41.67\%), Berilius varga (41.67\%), Lebio dyocheilus (50\%), Lebio dero (50\%) and Nemeculus rupicola (58\%), collected from the sampling site, were noted under the common category. Nemechelius bevani $(33.33 \%)$ and Nemachelius montanous (25\%) were the occasional species. None of the species was rare.

During the entire study period (Jan., 2013 to Dec., 2013) the maximum number of collected fish 
species 11 was noted in the month of September and December and the minimum number of fish species 04 was noted in the month of June. Monthly composition of fish species in terms of quality and quantity at the selected sampling site of the river Kosi is mentioned in table (3).

Table 3: Monthly qualitative composition of fish diversity at sampling station Kosi of river Kosi during study period (Jan., 2013 to Dec., 2013).

\begin{tabular}{|c|c|c|c|c|c|c|c|c|c|c|c|c|c|}
\hline E্் & $\underset{\sigma}{\Xi}$ & & & & & & & & & $\overline{\tilde{e}}$ & $\vec{z}$ & & $\stackrel{\widetilde{\pi}}{\underline{\sigma}}$ \\
\hline T. putitora & + & + & + & - & + & + & + & + & + & + & + & & $\begin{array}{l}1 \\
1\end{array}$ \\
\hline T. tor & - & - & - & + & - & - & + & + & + & - & - & & $\begin{array}{l}0 \\
5\end{array}$ \\
\hline $\begin{array}{l}\text { S. } \\
\text { richardso } \\
\text { nii }\end{array}$ & + & + & + & + & + & + & + & + & + & + & + & & \\
\hline $\begin{array}{l}S . \\
\text { plagiosto } \\
\text { mus }\end{array}$ & + & + & + & + & + & + & + & + & + & + & + & & \\
\hline $\begin{array}{l}\text { B. } \\
\text { bendelisis }\end{array}$ & + & + & - & - & + & - & - & + & + & + & + & & $\begin{array}{l}0 \\
8\end{array}$ \\
\hline B. varga & - & - & - & + & + & - & - & - & + & + & - & & $\begin{array}{l}0 \\
5\end{array}$ \\
\hline G. gotyla & + & + & + & + & + & + & + & + & + & + & + & & $\begin{array}{l}1 \\
2\end{array}$ \\
\hline $\begin{array}{l}\text { L. } \\
\text { dyocheilus }\end{array}$ & + & - & - & + & + & - & - & - & + & + & - & 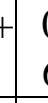 & $\begin{array}{l}0 \\
6 \\
\end{array}$ \\
\hline L. dero & + & + & - & + & - & - & - & + & + & + & - & & $\begin{array}{l}0 \\
6\end{array}$ \\
\hline N. beavani & + & - & - & - & - & - & - & - & + & - & + & & $\begin{array}{l}0 \\
4\end{array}$ \\
\hline $\begin{array}{l}N . \\
\text { rupicola }\end{array}$ & - & + & + & - & + & - & - & - & + & + & + & & $\begin{array}{l}0 \\
7\end{array}$ \\
\hline $\begin{array}{l}N . \\
\text { montanus }\end{array}$ & - & - & - & - & - & - & - & - & - & + & + & & $\begin{array}{l}0 \\
3 \\
\end{array}$ \\
\hline Total & $\infty$ & E & & E & $\infty$ & ty & ?. & 5 & 二 & 은 & $\stackrel{\infty}{\infty}$ & & \\
\hline
\end{tabular}

\section{Discussion}

Fishes are the integral part of an aquatic ecosystem. Fresh water bodies like rivers, ponds and lakes etc. posses specific water quality, which in turn, alters the abundance and the population size of different fish species. Even the same river draining from hills to plain depicts a great population difference in fish species as the altitude of the river bed lowers down gradually. A number of research works has been done on fish diversity on rivers, reservoirs, ponds and lakes. The observed data from the present study on fish species richness in the river Kosi was compared with the reports from different water bodies of India. 40 fish species in a study on upper ganges basin were observed [10]. 18 fish species were recorded in Western Ramganga river [15]. In another study on Western Ramganga river, 14 fish species were observed [1]. 42 fish species were recorded in middle Himalayan water resources [14].

\section{Conclusion}

In the present study on the river Kosi 12 species of hill stream fishes were observed. All the fish species found in the river were characterized with some special adoptive organs to survive in hill streams. The presence of these fish species indicates that the ecosystem of Kosi river is suitable for the survival of fish diversity.

\section{References}

[1] A. Pandey, H. C. Upadhyay, "Fish Diversity in Western Ramganga River of Kumaun Himalaya Uttarakhand, India," International Journal of scientific research and management, 4(11), pp. 4872-4879, 2016.

[2] D. A. Jackson, P. R. Peres-Neto, J. D. Olden, "What controls who is where in freshwater fish communities - the roles of biotic, abiotic and spatial factors," Can. J. Fish. Aquat. Sci., 58(1), pp. 157-170, 2001.

[3] D. Dudgeon, A. H. Arthington,, M. O. Gessner, Z. I. Kawabata, D. J. Knowler, "Freshwater biodiversity: Importance, threats, status and conservation challenges," Biol Rev., 81, pp. 163-182, 2006.

[4] D. E. Cowley, "Strategies for ecological restoration of the Middle Rio Grande in New Mexico and recovery of the endangered Rio Grande silvery minnow," Rev. Fish. Sci., 14(12), pp. 169-186, 2006.

[5] D. E. Cowley, R. C. Wissmar, R. Sallenave, "Fish assemblages and seasonal movements of fish in irrigation canals and river reaches of the middle Rio Grande, New Mexico (USA)," Ecol. Freshw. Fish, 16(4), pp. 548-558. 2007.

[6] D. J. Hoeinghaus, K. O. Winemiller, J. S. Birnbaum, "Local and regional determinants of stream fish assemblage structure: inferences 
based on taxonomic vs. functional groups," J. Biogeogr., 34(2), pp. 324-338, 2007.

[7] F. Day, The fishes of India: being a Natural History of the Fishes known to inhabit the seas and Fresh waters of India, Burma and Ceylon. Reproduced in 1958, London: Willian Dawon and Sons, 1878.

[8] K.C. Jaya Ram, Fundamentals of fish Taxonomy, Narendra Publishing House, Delhi, 2002.

[9] K. Kumar, K. K. Rautela, K. L. Bisht, V. D. Joshi, A. S. Rautela, A. K. Dobriyal, "Ecological studies on the Biodiversity of river Khoh in the foothills of Garhwal Himalaya," Journal of Natcon, 18, pp. 71-80, 2006.

[10] K. Pathak, U. K. Sarkar, S. P. Singh, "Spatial gradients in freshwater fish diversity, abundance and current pattern in the himalayan region of upper ganges basin, India," Bio diversit as, 15(2), pp. 186-194, 2014.

[11] K. Rautela, K. Bisht, K. L. Joshi, V. D. Negi, K. S, A. S. Rautela, A. K. Dobriyal, "Ecological studies on the biodiversity of river Khoh in the foot hills of Garhwal Himalaya," Aquaculture, 7, pp. 277-283, 2006.

[12] P. K. Sahu, J. K. Jena, P. C. Das, S. Mondal, R. Das, " Production performance of Labeo calbasu (Hamilton) in polyculture with three Indian major carps Catla catla (Hamilton), Labeo rohita (Hamilton) and Cirrhinus mrigala (Hamilton) with provisions of fertilizers, feed and periphytic substrate as varied inputs," Aquaculture, 262, pp. 333-339, 2007.

[13] R. A. Mittermeier, C.G. Mittemeier, Megadiversity: Earth's BiologicallyWealthiest Nation. In: Global Freshwater Biodiversity, (Ed.) McAllister, D. E., Hamilton, A. L. and Harvery B., SeaWind, Cemex, Mexico City, 11, pp. 1-140, 1997.

[14] R. Verma, "Water and fishery resources of Kumaun central Himalaya, India," Discovery, 8(19), pp. 7-12, 2013.

[15] S. S. Pathani, K. K. Upadhyay, "An inventory on zooplankton, zoo-benthos and fish fauna in the River Ramganga (W) of Uttaranchal, India," Himalayan Ecology ENVIS Bulletin, 14(2), pp. 37-46, 2006.

[16] T. J. Haxton, C. S. Findlay, "Meta-analysis of the impacts of water management on aquatic communities," Can. J. Fish. Aquat. Sci., 65(3), pp. 437-447, 2008.

[17] T. Light, M. P. Marchetti, "Distinguishing between invasions and habitat changes as drivers of diversity loss among California's freshwater fishes," Conserv. Biol., 21(2), pp. 434-446, 2007.

Author profile

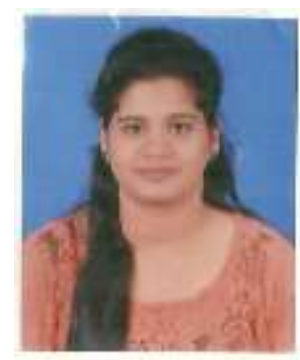

Babita Selakoti received the degrees of B.Sc. and M.Sc. in Zoology from Kumaun University, Nainital in 2008 and 2010 respectively. In November 2017 she got the degree of Ph.D. from Kumaun University, Nainital 
International Journal of Scientific Research and Management (IJSRM)

||Volume||06||Issue ||02||Pages||B-2018-01-04||2018||

Website: www.ijsrm.in ISSN (e): 2321-3418

Index Copernicus value (2015): 57.47, (2016):93.67, DOI: 10.18535/ijsrm/v6i2.b01 